\title{
Implementation Enforcement Embezzlement Of Rental Vehicle Crime In Polsek Banyuurip Satker Polres Purworejo
}

\author{
Tito Dwi Anggoro ${ }^{1}$
}

Abstract. The purpose of this research is to know and analyze the mode of the crime of embezzlement of the car in case Number: BP / 07 / V / 2016 / Criminal in police Banyuurip-Purworejo, to know the investigation on the case, and to know and analyze the obstacles and find solution in the law enforcement process on the perpetrators of criminal fraud in the case of cars Number: B / 145 / V / 2016 / Sek BU Banyuurip Police in Purworejo. This study uses a normative Juridical approach with a specific case study of car embezzlement in Purworejo District. Data collected from case Document Number: BP / 07 / V / 2016 / Criminal then it was Analyzed by using qualitative analysis. The results Showed that the mode of cars embezzlement crime is done by doing the rental activity. That criminal act committed by private employees who rented cars. The reason in using Reviews those cars was for the company's business for two days. The investigation of the case is based on the police report number: LP / B / 09 / V / 2016 / Java / Res Pwr / Sek Bu dated May 2, 2016 about fraud and / or embezzlement. There was no search was done. In the confiscation, some evicences were taken. They were 1 cellphone, 1 BCA book saving, 1 BCA ATM, 1 transaction details at BCA saving, 1 car loan notes, US \$ 10,000,000 cash, -, and BPKB guarantee letter from CIMB Niaga bank Yogyakarta. Keywords: Criminal Law Enforcement, Car Rental Embezzlement.

\section{Introduction}

Today, the cases of car fraud happen very frequently in many areas, Including Purworejo District. Reviews These cases occur as the development of car rental services. Business opportunities in the field of car rental are very good because of the higher demand siring economic growth and human mobility recently. From the Data Obtained from Tempo magazine, from 1.5 million units of operational vehicles factory in Indonesia, 415,000 units belong to the rental car. This is a parameter that the need for rental vehicles is still high in Indonesia Including in Purworejo District.

Practically, Became a car rental business targets of crime by Irresponsible elements. This is marked by the occurrence of fraud and embezzlement car Suffered by the owner of the rental car service with the mode of not returning, selling, mortgaging or leased the car from the car rental company. As the result, the car rental service owners underwent some material losses.

One example of rental vehicles Attracted embezzlement cases that people's attention is the embezzlement of 20 cars handled by the Police Metro Tangerang in November 2017. It was done by buying vehicles from debtors who still have credit and resold to others. ${ }^{2}$

From the investigation conducted by the Police Metro Tangerang, the vehicles were sold in the north coast region, such as Cirebon, Tegal, Kendal, Pacitan to Surabaya. According to

\footnotetext{
${ }^{1}$ Student Masters (S-2) of law UNISSULA Semarang and Member of Bagren (Division of Planning Police Resort of Purworejo) Polres Purworejo email: sniperporjo@gmail.com

2 Gelapkan 20 Mobil 4 Orang Ditangkap di Tangerang 10 November 2017 https://news.detik.com/berita/d-3721644/gelapkan-20-mobil-4-orang-ditangkap-di-tangerang, In the access date May 192018
} 
the recognition of the suspect, a car was purchased at a price of $\mathrm{Rp} 30$ million. Then, it was resold for USD 35 million. From the four suspects, policemen Seized 20 units of the car yielded from embezzlement. Benefits Obtained by the suspects Reached Rp 100 million.

The same thing, Although not in a large scale, occurred in the jurisdiction of Purworejo. At the beginning, the Offender rented a car for 2 days for an office activity. After the car was in the Renter's hand, it was pawned for Rp 25,000,000, - to three unknown people. Until the reporting day on Monday March 2, 2016, the suspect, the perpetrator, and the car itself disappeared.

Although the crime of four-wheeled vehicles rental embezzlement rarely happen, this case causes an awareness of the car rental business. As the result, law enforcement officers should give a serious response. This case will lead to the reduction of public confidence to the Police institution. Moreover, there will be no trust from car owners to society. Consequently, it will prejudice the community itself as a party that requires the rental of vehicles, especially for Purworejo resident.

Based on the above background exposure, it is Appropriate to do research about cases of car embezzlement that occurred in the legal district of Purworejo. In line with the problems to be studied, the topic of the research taken is the law enforcement process of car embezzlement in the National Police of Purworejo with the aim of knowing and analyzing the mode of criminal embezzlement car rental with Number: BP / 07 / V / 2016 / criminal and to know and analyze the obstacles and find solutions in law enforcement on the Offender of criminal embezzlement of rental car in the case Number: BP / 07 / V / 2016 / criminal.

\section{Research Methods}

The type of this research is empirical Juridical. It is a type of sociological legal research. It can also be done with field research the which examines the applicable legal provisions and what happens in reality in society. , 3

Judging from the type of data, the research approach used in this research is a qualitative approach. The qualitative research is intended to understand the phenomenon of what is experienced by the subject of research holistically, and by description in the form of words and language, in a special context and by utilizing various scientific methods.

This research is included in the descriptive-analytical study of law that describes the applicable legislation and connected to premises law theories and practice of the implementation of positive law that concerns the problem ${ }^{4}$, It is expected to Obtain a comprehensive, and systematic description of the research focus. Then, the Data Obtained will be Analyzed. While analytical Because The Data Obtained will be Analyzed ${ }^{5}$

In this research, the data used are the primaries of data and secondary data. Primary Data Obtained is the data from the first source directly related to the issues to be Discussed. In this study, the primary source of data is Obtained from the files of the case in Banyuurip Police, Purworejo Number: BP / 07 / V / 2016 / Reskrim about embezzlement of rental car.

\footnotetext{
3 Bambang Waluyo 2002 Penelitan Hukum Dalam Praktek Jakarta Sinar Grafika p.15

${ }^{4}$ Ronny Hanitijo Soemitro 1988 Metode Penelitian Hukum dan Jurimetri Jakarta Ghalia Indonesia p. 38

5 J. Vrendenbregt in his book entitled "Metode dan Tehnik Penelitan Msyarakat" tells that in the type of descriptive research it is endeavored to provide a clear description of a collectivity. The representative must be assured. The main purpose of descriptive research is to describe the complex social reality in such a way so that the relevance of an anaphological socio-logy is achieved.
} 
Furthermore, the data is a secondary Data Obtained from a study literature search by studying various literature, official documents, and laws related to the object of research, whether it's primary legal materials, secondary legal materials, and tertiary legal materials ${ }^{6}$,

This research uses documentary technique of data collection method from the case file Number: BP / 07 / V / 2016 / Criminal. By reviewing the document, it is expected to produce an accurate research in answering some problems related to criminal embezzlement of the car rental, the process of investigation, the constraints, and the solutions. In order to complete the documentation techniques, interviewing and observation methods are Also required. Interviews were conducted on informants who understood the issues under investigation. Then, observation methods were used to complement and Ensure the data collected. Reviews These techniques are sufficient to answer the problems Discussed in the study.

\section{Results And Discussion}

\subsection{The Concept of Criminal Deeds According to Article 372}

The term of "criminal offense" by experts does not extinguishing it from the Latin word derived from delictumor delicta. In Dutch, it is known as strafbaarfeit, consisting of straf means "law" means baar "can" or "may" and fait means "event". Criminal law experts use that word in various terms with Reviews their respective points of view",

The formulation of the "criminal offense" contained in Article 372 of the Criminal Code of Book II of the Criminal Code is intentionally Possessed by violating the law of a good wholly or partly belonging to another person and under his authority (onder zich hebben) of than by committing a crime. Elements have goods with violating the law is Sufficiently Discussed on the criminal act of theft. ${ }^{8}$

It is also added that the goods must exist under the principal's power in other ways than by committing a crime. Thus, it is illustrated that the item is by the owner entrusted or may be deemed entrusted or may be deemed entrusted to the Offender. So, in essence with the act of embezzlement, the Offender does not fulfill the abandoned belief is or may be deemed delegated to him by the entitled to a good.

The term of criminal offenses are as described by some experts as follows.

- According to Vos, a crime is a misdeed that is threatened by legislation, so a behavior is prohibited by criminal penalties Generally ${ }^{9}$

- According to Simons, a criminal offense is a behavior of the which is threated with crime, against the law, and has a relationship to wrong thing, and committed by a responsible person. ${ }^{10}$

- According to Prodjodikoro, a criminal offense is an act Whose perpetrators are given criminal penalties. ${ }^{11}$

\footnotetext{
${ }^{6}$ Soerjono Soekamto 2014 Prosedur Penelitian Suatu Pendekatan Praktik Jakarta: Rineka Cipta

${ }^{7}$ Andi Hamzah 2009 Delik-Delik Tertentu (Speciale Delicten) di Dalam KUHP Sinar Grafika Jakarta p. 88.

${ }^{8}$ Wirjono Prodjodikoro Tindak-Tindak Pidana Tertentu di Indonesia Jakarta PT Refika Aditama 2003 p.31.

${ }^{9}$ Tri Andrisman Hukum Pidana Universitas Lampung 2007 Bandar Lampung p. 81

${ }^{10}$ Ibid.

${ }^{11}$ Ibid.
} 
- Pompe criminal act defines as a violation of the norm, done because of the perpetrated by misconduct and criminal penalties to defend the rule of law and to save the general welfare. Whereas According to positive law, it is an incident roomates legislation is Formulated by law as punishable acts. ${ }^{12}$

- According to Moeljatno, a crime is an act that has elements and two related properties. Reviews These elements can be divided into two kinds:

- Subjective, the which is related to the DOER himself, included everything contained in his heart.

- Objective, the which is an inherent element in the DOER or that have a relationship to Reviews their circumstances, ie, in the circumstances in the which the actions of the DOER must be done. ${ }^{13}$

\subsection{Type of Criminal Act of Embezzlement}

The criminal act of embezzlement is set out in Book II of Chapter XXIV of the Criminal Code (Penal Code) entitled "Destruction". The criminal act of embezzlement is regulated in Articles Several items, namely Article 372 up to Article 377 of the Criminal Code the which contains:

- Article 372

"Whoever intentionally and unlawfully owns the goods, wholly or partly belongs to another person, and only exists to him not Because The crime, is punished by Imprisonment for four years or a fine of up to 15 times sixty rupiah"

- Article 373

"The act Described in Article 372, when the embezzlement is not cattle and costs not more than two hundred and fifty thousand rupiah, is punished as a light embezzlement, with a maximum Imprisonment of three months or a fine of up to 15 times sixty rupiah ".

- Article 374

"The embezzlement perpetrated by the person who holds goods because of his own position or because of his job or for money, is punished with Imprisonment maximally for five years".

- Article 375

"The embezzlement of persons to him shall be compelled to be deposited, or by a guardian, a custodian, a caretaker, a person who carries out a will, a charity or foundation's board of goods on their behalf, is sentenced maximally for six years Imprisonment".

- Article 376

"The rules of Section 376 apply to the crimes Described in this chapter".

Based on many Articles Mentioned above, the criminal act of embezzlement can be classified into types Several items, namely:

- Embezzlement in principal form

- Light evasion

- Embalming with weeding.

${ }^{12}$ Ibid.

${ }^{13}$ Moeljatno1993 Azas-Azas Hukum Pidana Rineka Cipta Jakarta p. 69 
- Embezzles as offense complaints.

- Embezzlement by Civil Servants because of his position.

According to Moeljatno, the types of crime are distinguished on Certain grounds. They are stated as follows: ${ }^{14}$

- According to the Penal Code (Penal Code), types of crimes are distinguished between crimes contained in Book II and the violations contained in Book III. The division of crime into "crime" and "offense" is not only the basis for the division of our Criminal Code into Book II and Book III, but Also the basis for the entire system of criminal law in the Laws as a whole.

- According to how to formulate it, it is differentiated in formal crime (formeel Delicten) and material offense (Material Delicten). Formal criminal offense is a criminal act that is formulating that the prohibition is doing Certain Formulated deeds. For example Article 351 of the Criminal Code is about persecution. The core of the criminal offense of the prohibition is on causing the forbidden effect. Therefore, who causes the forbidden effect is the person who is responsible and convicted.

- Viewed from the form of wrongdoing, the crime is distinguished into a deliberate crime (dolus delicten) and an accidental crime (culpose delicten). Examples of intentional punishment (dolus) regulated in the Criminal Code include the following: Article 310 of the Criminal Code (defamation) is deliberately attacking the honor or good name of a person, Article 322 of the Criminal Code (unlocking) is deliberately open a that must be kept secret because of his position or search. On the offense of Negligence (culpa), one can also be punished if there are errors, such as Article 360 Paragraph 2 of the Criminal Code the which causes others to be Injured.

- Based on their actions, crime is divided into two. They are:

- Formulated Pure crime is a criminal offense or a criminal offense the which is basically an element of action in the form of passive acts, for example stipulated in Articles 224.304 and 552 of the Criminal Code.

- Non-pure criminal act is a crime the which is basically a positive criminal act, but can be done inactive or criminal act containing prohibited substance but done by not doing, for example regulated in Article 338 of the Criminal Code such as a mother does not breastfeed her baby so that the baby Died.

Based on the explanation above, it can be concluded that the types of criminal acts Consist of criminal offenses and criminal offenses, crimes formal and material offenses, criminal deliberate unlawful acts and crimes, and active and passive crime.

The criminal acts contained in article 372 of the Code of Criminal Law are the principal criminal offenses. As Provided in Article 372 to Article 377 of the Criminal Code, the criminal act of embezzlement is not a criminal act the which is included in a criminal offense against a person's property or vermogensdelicten.

According to Cleiren et.al, cited by Andi Hamzah, the core of the offense of embezzlement is belief misunderstanding. It always involves unlawfully possessing the goods entrusted to the person who is embezzling it. ${ }^{15}$

\subsection{The Elements of Criminal Acts of Embezzlement}

\footnotetext{
${ }^{14}$ Ibid p.47

${ }^{15}$ Andi Hamzah Delik-Delik Tertentu (Special Delicted) di Dalam KUHP Edisi Kedua Jakarta p. 97
} 
The criminal acts of fraud and embezzlement in the Criminal Code are set forth in Book II on Crimes against Property, the which is in the form of an attack on the legal interests of the person for his property. In general, the elements of criminal acts against assets Reviews These include the objective and Subjective elements ${ }^{16}$

Its Subjective element consists of:

- Elements of errors Formulated with words such as "with intent", "intentionally", "the which he knows / is suspected of by him" and so on;

When connected with the intentions contained in a formulation of criminal acts such as in embezzlement, the deliberate is said to exist if there is a will or the existence of knowledge of an act or things / Certain elements (Mentioned in the formulation) as well as want and or know or Realize the consequences Arising from deeds.

- Elements against the law roomates are both explicitly stated / written in the formulation of the article or not.

Basically, against law is forbidden act. There are two kinds of unlawful acts. They are against the formal law and against the material law.

While the objective elements are:

- Elements of material deed, possessing / claiming (in the case of embezzlement). The notion of "possession" has the form of an objective element. It is an element of behavior or a forbidden act, or a form of perceived possession. For example: selling, swapping, granting, mortgaging, etc.

- Elements of objects;

- The element of the Accompanying state of the object. The object itself must belong to another;

- Efforts of certain elements used in committing a prohibited act;

- Constitutive element Arising after the prohibited act.

From the results of the research, the mode of criminal offense occurred in Purworjeo district handled by the Police of Banyuurip based on the file of the case: BP / 07 / V / 2016 / Criminal is a private employee on behalf of Devi Raharjo son of Herman Susanto borrowed a car from Ning Sulastri or Mrs. Samino bint Supaman by Stating a reason for the operational purposes of the office for two days. After she took the car, she mortgaged it with the amount of $\operatorname{Rp} 25,000,000$, -

In the context of criminal law enforcement, it is Necessary to review the opinions of experts, Including the case of embezzlement of cars in this study. According to Soerjono Soekanto, law enforcement is an activity of harmonizing the values that are outlined in the steady rules as a series of final value stages. It is used to create, and maintain peace of life. ${ }^{17}$ Enforcement of criminal law is the application of criminal law by law enforcement officers concretely. ${ }^{18}$

16 Unsur-Unsur Tindak Pidana Penipuan dan Penggelapan 15 September 2012 http://irwanandrianto.blogspot.co.id/2012/09/unsur-unsur-tindak-pidana-penipuan-dan.html, In the access date May 152018

${ }^{17}$ Soerjono Soekanto 1983 Faktor-faktor Yang Mempengaruhi Penegakan Hukum Jakarta UI Press p. 35

18 M.Faal 1991 Penyaringan Perkara Pidana Oleh Polisi (Deskresi Kepolisian) Jakarta PT PradnyamParamita p. 42. 
According to Andi Hamzah, the terms of law enforcement includes repressive and preventive. ${ }^{19}$ The latest law enforcement Also includes restorative or rehabilitative. It has the same meaning with the Dutch term rechtshandhaving. In English term, repressive law enforcement has meaning. The preventive meaning in English is in the form of giving information, persuasion, and instructions.

Criminal law enforcement is a unified process beginning with investigation, arrest, detention, trial of defendant and ended with correctional prisoner. ${ }^{20}$

In other words, criminal law enforcement is the imposition of criminal regulations. Thus, law enforcement is a system that involves harmonizing the rules and values of real human behavior. Reviews These rules then Become guidelines for behavior or stereotypes that are deemed appropriately. This behavior is Aimed at creating, preserving, and maintaining peace.

Law enforcement disorder sometimes happens if there is inconsistency between the rules and behavior patterns. The disturbance Occurs between the pinned values roomates are incarnate in the muddles and the unfocused behavior patterns that disturb the life of the life association. Therefore it can be said that the enforcement of law is not Merely the implementation of the law.

In the context of law enforcement of embezzlement in Purworejo District, the initial step of the investigation has been done. The investigation started with a Police Report Number: LP / B / 09 / V / 2016 / Central Java / Res Pwr / Sek Bu dated May 2, 2016 or about fraud and embezzlement and Investigation Order Number: SP.Sidik / 11 / V / 2016 / Criminal dated May 2nd, 2016 and Letter of Notice of Commencement of Investigator (SPDP) Number: B / 07 / V / 2016 / Criminal dated May 9, 2016.

The investigation has been Carried out by the seizure in the form of one mobile phone brand Nokia, one savings Stages of BCA with account number 4230366093 roomates belongs to Devi Raharjo issued by KCP Kebumen, one BCA yellow ATM with serial number 6019002641971793, one detail transaction merger Stages Bank account number 4230366093 on behalf of Devi Raharjo, a note of borrowing Alif Trans Managemen car with the contents of the memo of one unit Daihatshu Xenia white car color number AA8569FC on Wednesday March 2, 2016 at 20:00 PM by name Devi Raharjo with the receipt of the vehicle on behalf of Devi Raharjo / EkoWatiningsih, cash of Rp 10,000,000, - (Ten million rupiah), one sheet of the certificate issued by PT. CIMB Niaga Auto Finance in Yogyakarta dated May 11, 2016 about the assurance of ownership of reg.

There were no significant obstacles in the investigation process. The investigation proceeds According to plan so that it is Effectively implemented a both Juridical and sociological.

\section{Conclusion}

Based on the above discussion, the problems in this research can be concluded as follows:

- The criminal mode of embezzlement of a private employee on behalf of Devi Raharjo son of Herman Susanto is that she borrowed a car from Ning Sulastri or Mrs. Samino

\footnotetext{
${ }^{19}$ Andi Hamzah Reformasi Penegakan Hukum Pidato Pengukuhan Jabatan Guru Besar pada Fakultas Hukum Unviersitas Trisakti Jakarta p. 2.

${ }^{20}$ Harun M.Husen 1990 Kejahatan dan Penegakan Hukum Di Indonesia Jakarta :Rineka Cipta p 58
} 
bint Supaman by Stating a reason for the operational purposes of the office for two days. After she took the car, she mortgaged it with the amount of $\mathrm{Rp} 25,000,000$, -.

- The investigation started from a Police Report Number: LP / B / 09 / V / 2016 / Java / Res Pwr / Sek Bu dated 02 May 2016 and confiscated some evidence while the vehicle is still in the searching process.

- There were no significant obstacles in the investigation. The investigations run smoothly According to the plan.

\section{Bibliography}

[1] Bisnis Penyewaan Mobil Makin Menjanjikan 24 Mei 2013 https://bisnis.tempo.co/read/483009/bisnis-penyewaan-mobil-makin-menjanjikan di akses tanggal 9 mei 2018

[2] Bambang Walouyo 2002 Penelitan Hukum Dalam Praktek Sinar Grafika,Jakarta

[3] Ronny Hanitijo Soemitro 1988 Metode Penelitian Hukum dan Jurimetri Ghalia Indonesia Jakarta

[4] Amiruddin 2006 Pengantar Metode Penelitian Hukum PT Raja Grafindo Persada Jakarta

[5] Soerjono soekamto 2014 Prosedur Penelitian Suatu Pendekatan Praktik Rineka Cipta Jakarta

[6] Andi Hamzah 2009 Delik-Delik Tertentu (Speciale Delicten) di Dalam KUHP Sinar Grafika Jakarta

[7] Wirjono Prodjodikoro 2003 Tindak-Tindak Pidana Tertentu di Indonesia PT Refika Aditama Jakarta

[8] Tri Andrisman 2007 Hukum Pidana. Universitas Lampung. Bandar Lampung

[9] Moeljatno 1993 Azas-Azas Hukum Pidana Rineka Cipta Jakarta

[10] Soerjono Soekanto 1983 Faktor-faktor Yang Mempengaruhi Penegakan Hukum UI Press Jakarta

[11] M.Faal 1991 Penyaringan Perkara Pidana Oleh Polisi (Deskresi Kepolisian) PT PradnyaParamita Jakarta

[12] Andi Hamzah 1998 Reformasi Penegakan Hukum Pidato Pengukuhan Jabatan Guru Besar pada Fakultas Hukum Unviersitas Trisakti Jakarta

[13] Harun M.Husen 1998 Kejahatan dan Penegakan Hukum Di Indonesia Rineka Cipta Jakarta

[14] Moleong Lexy 2007 Metodologi Penelitian Kualitatif Bandung: Remaja Karya.

[15] Unsur-Unsur Tindak Pidana Penipuan dan Penggelapan 15 September 2012 http://irwanandrianto.blogspot.co.id/2012/09/unsur-unsur-tindak-pidana-penipuandan.html di akses tanggal 15 Mei 2018

[16] Gelapkan 20 Mobil 4 Orang Ditangkap di Tangerang 10 November 2017 https://news.detik.com/berita/d-3721644/gelapkan-20-mobil-4-orang-ditangkap-ditangerang di akses tanggal 19 Mei 2018 